\title{
17 \\ THE RACIAL CONTOURS OF QUEER REPRODUCTION
}

\author{
France Winddance Twine and Marcin Smietana
}

[Q]ueer happens precisely when [...] bodies meet that would be kept apart if we followed the lines given to us.

(Sara Ahmed 2006: 148-149)

Queer kin relations clearly overlap with, and sit alongside, established forms of family while simultaneously holding elements that can and often do emerge to disrupt congruence.

(Aaron Goodfellow 2015: 64)

In our earlier work (Smietana, Thompson, and Twine 2018), we argued for reading queer kinship from the perspective of stratified reproduction and reproductive justice. In that work, we called for studying LGBTQ reproductions and queer kinships from the perspective of intersectional inequalities in which multiple participants in the reproductive process may be immersed: LGBTQ (intended) parents, surrogate mothers, gamete donors, and birth families in adoption. We argued for reproductive rights for both LGBTQ parents and those people who help them create families.

Our goal in this chapter is to build upon the foundational literature in queer theory and bring it into dialogue with critical race studies. We provide an analysis of family formation that departs from some of the earlier literature in the anthropology of reproduction in its sustained focus on the central role that racial hierarchies and racial logics play. We ask two questions. First, how does the literature in queer kinship engage with the issues of race, class, and intersecting inequalities? In this chapter, we refer to family formations that have crossed racial, class, or caste barriers-not just to gender and sexual transgressions. We use the term transgressive to refer to family forms that do not conform to heteronormative, monoracial models that do not employ assisted reproductive technologies. What is considered transgressive is historically contingent and culturally specific.

Second, our chapter contributes to ongoing debates in anthropology that illuminate the social, cultural, and political imperatives that confer respectability and legitimacy to the reproduction of transgressive family forms. Given the changing legal and global landscape, we offer a nuanced analysis of the ways that queer families employ racial and cultural logics as they engage with technologies in their pathways to parenthood. Our analysis also demonstrates the ways 
that heteronormativity and Whiteness mark all logics of reproduction in the early twenty-first century.

Surrogacy contracts and donor agreements are cultural transactions as well as economic ones. Thus, it is impossible not to see class at work in these transactions. It is evident that employing ART or adoption to form a family if one identifies as LGBTQ requires economic resources that place reproduction outside of the realm of possibility for impoverished or working-class people. The intersections of social class hierarchies with heteronormativity and structural racism have not been the main focus of the foundational studies of queer families. One exception has been the work of Yvette Taylor (2009), who examined social class in lesbian and gay families in the UK. In this chapter, we provide an intersectional analysis that centers race in the anthropology of reproduction. Elsewhere we consider the role of class, locality, and nationality in the ongoing choreographies involved in queer family formation (Twine 2015; Smietana 2017; Smietana \& Twine n.d.)

In the following sections, we first define the meanings of "queer" and introduce the foundational literature on "queer kinships." Following Charis Thompson's (2005) work on strategic naturalization, we propose the term "choreography of queer kinship" in order to show how in the creation of kinship, sexuality is mobilized in multiple configurations together with race and class. In this paper, we focus our attention in particular on race, as we discuss examples of scholarship that reads queer kinships and race together.

\section{The meanings of queer}

The meaning and boundaries of queer are contested and provisional and have always reflected colonial, neocolonial, and postcolonial categories. In Kim TallBear's (2018) analysis of the "compulsory settler sex, family and nation," she argues that in North America, "the aspirational ideal of middle-class nuclear family, including (hetero)normative coupledom with its compulsory biological reproduction" (151) has been imposed on Indigenous peoples' extended family structures that historically included what today would be called consensual non-monogamy, as well as on their relationships to non-human species and the land. TallBear argues that this imposition serves the patriarchal heteronormative, and increasingly also homonormative, imperial state, and turns a decolonial lens toward normative marriage and family formations:

[In Dakota Kinship] more than two genders were recognized, and there was an element of flexibility in gender identification. [...] The record is also clear that there was plural marriage [...]. As I try to write this, I engage in essentially nonsensical conceptual time travel with categories that will lose their integrity if I try to teleport them back or forward in time. So much has gone dormant-will go dormant. So much has been imposed onto Indigenous peoples, both heteronormative settler sexuality categories and now also "queer" categories.

(TallBear 2018: 153)

In the (post-)colonial context of North America, Gloria Anzaldúa (1981) may have been the first scholar to use the term queer in her autohistorical essay, "La Prieta." She described her childhood experiences as a particularly dark-skinned Mexican in Texas: "it was too bad I was dark like an Indian" (Anzaldúa 1981: 38). Here we see skin color, or what Margaret Hunter (2002, 2007) has studied as colorism, as a negative difference. Anzaldúa reminisced about her mother's attempts to hide those differences, where her family worked as agricultural workers in Texas. Despite her "mother and brothers calling me jota (queer) when I told them my friends 
were gay men and lesbians" (1981: 44), in her seminal essay Anzaldúa moved on to discuss the political "borderlands" of not belonging and exclusion, from which "the queer groups" could work together to build alliances:

The rational, the patriarchal, and the heterosexual have held sway and legal tender for too long. Third World women, lesbians, feminists, and feminist-oriented men of all colors are banding and bonding together to right that balance. Only together can we be a force. I see us as a network of kindred spirits, a kind of family. We are the queer groups, the people that don't belong anywhere, not in the dominant world nor completely within our own respective cultures.

(Anzaldúa 1981: 50)

Sara Ahmed (2006) also wrote about how her skin color made her experience "queer" in the context of predominant whiteness in Australia and the UK:

Colonialism makes the world "white," which is of course a world "ready" for certain kinds of bodies, as a world that puts certain objects within their reach. [...] The "matter" of race is very much about embodied reality; seeing oneself or being seen as white or black or mixed does affect what one "can do," or even where one can go, which can be redescribed in terms of what is and is not within reach. If we begin to consider what is affective about the "unreachable," we might even begin the task of making "race" a rather queer matter.

(Ahmed 2006: 111-112)

When Teresa de Lauretis (1991: x) first used the term queer theory at the 1990 conference she organized at the University of California, Santa Cruz, she searched for a term and for politics that could be more useful and less exclusionary than "lesbian and gay," given the dominance of the White male middle-class perspectives in the representation of sexualities at the time. "Racial as well as gender differences are a crucial area of concern for queer theory," De Lauretis wrote (1991: x, xi).

Thus, an intersectional understanding of sexuality has been one of the very aims of queer theory from the beginning. A number of scholars have built upon these definitions of queer and emphasized intimate and sometimes paradoxical links between sexuality, race, and nation (e.g., Duggan 2002; Puar 2007; Ahmed 2011; Bacchetta and Haritaworn 2011). They have shown how liberal narratives of sexuality and LGBTQ rights can sometimes be blind to the politics of race and nation, and therefore they have called for reading sexuality and race and nation together.

Ahmed (2006) conceptualized queer as those relationships and kinships that are considered to be "out of place," "mixed," not "like," uncomfortable. In the larger context of compulsory heterosexuality Ahmed argues that "queer happens precisely when [...] bodies meet that would be kept apart if we followed the lines given to us" (2006: 148-149). In particular, queer scholars such as Ahmed have argued there are crucial links between the politics of sexuality and the politics of race. Following Ahmed and Anzaldúa, we employ queer as an elastic term, a placeholder for different kinds of transgressions, such as racial and class transgressions, alongside those in the realm of sexuality. LGBTQ may be one of the dimensions of queerness, whilst others can be, for example, racial or migrant status.

Aaron Goodfellow (2015: 162) provides a definition of queer kinship in his ethnography of families created by gay fathers in the US. Goodfellow's work calls attention to the ways that queer families are not "inherently" or always disruptive on all dimensions. His analysis illumi- 
nates the complexities of queer kinship and how it can be defined in ways that re-position middle-class White and sometimes interracial parents as respectable.

\section{New technologies and new family formations}

Writing about the emergence of IVF in the UK, Sarah Franklin (2019) reminds us about how the emergent consciousness was part of the social change:

The rapidly changing landscape of reproductive behavior during the 1970s was not only driven by legislative, demographic, and technological factors; it was also shaped by a moral and collective revolt, reflecting and expressing the declining influence of so-calledVictorian moral values, as well as increasing support for women's rights.

(Franklin 2019: 22)

New family formations were first created by lesbian and gay couples or singles through adoption, and later increasingly through in vitro fertilization (cf. Mamo 2007). For gay men, surrogacy offered the opportunity to have genetically related children. The default recognition of the genetic relatedness between the father and the child in many Euro-American kinship systems offered gay men a bulwark against discrimination as parents (Murphy 2015).

In both the US and UK, in the mid to late 1980s, married heterosexual couples with (in) fertility issues gained access to the so-called traditional surrogacy, where the gestational surrogate would use her own ovocytes. Subsequently, it took almost two decades before the technologies developed to enable up to five persons to claim parenthood: The sperm donor, the egg donor, the gestational surrogate, and the commissioning parents. Between 2000 and 2010, the technologies advanced so that male same-sex couples have more options in certain areas such as California to form a family "legally," with the support of agencies devoted to the legal and parental rights of same-sex couples. We recognize that ideologies and family formation practices occur in a dynamic legal context in which political and cultural movements demand or force changes in consciousness. Disciplinary practices and attitudes involving family formation are not static nor are the legal frameworks which intended parents negotiate.

A cursory review of earlier research on both LGBTQ and interracial family formation provides evidence that the grounds of struggle shifted as court cases were fought and/or won, reproductive technologies advanced, and political rights were granted in some regions (Weston 1991; Lewin 1993; Mamo 2007; Patton-Imani 2020). In her analysis of an important court case that expanded the notion of family rights to LGBTQ couples, Khiara Bridges (2014) notes that the US courts intervened in the debates about access to surrogacy, by "increasing recognition and legitimation of lesbian, gay, bisexual and transgender persons and the families that they have created" (1126). A significant contribution of Bridges' research is her identification of key distinctions between the "first-generation" of LGBTQ people who employed ART from the "second-generation." Firstgeneration fears structured family formation during an earlier era in ways that distinguished them from the concerns of the second generation. The fears of the first generation included losing custody of their children and/or not being recognized by the state as belonging to a family unit.

These LGBTQ histories of family formation have intensified under a neoliberal regime, as discussed by Laura Briggs (2017). The neoliberal privatization of care that has been ongoing since the early 1980s in the US, has hit both LGBTQ communities and racialized communities the hardest. In the face of HIV/AIDS and neoliberal racial and class politics, both LGBTQ and racialized communities were left without the safety net of state support provided to heterosexual families. 
Yet as the state did less and corporations did nothing to acknowledge or support the space to care for dependents, the outlaw status of gay households and communities became more and more unsupportable. If the only place that could care for dependents was "the (legally recognized) family," then gay people needed one too. Gay marriage, I am saying, is a reproductive politics issue.

(Briggs 2017: 150-151)

In 2010 and 2013, British music star Elton John and his now-husband David Furnish (who were in a civil partnership at that time) had two sons, born with the help of the same surrogate in California (John 2019). This happened in a legal context in which Furnish was legally identified as the co-parent and listed where the mother would have been on the birth certificate. This demonstrates the way the reproductive landscape had changed radically, at least for middle- and upper-middle-class men who have children in California. Elton John, who first came out as bisexual in the 1970s and then became a gay activist, now represents a family form that some call no longer "queer." In urban centers of countries like the US and UK, this family form has been getting increasingly normalized, including an industry and agencies to serve the transnational clientele in the US, as well as the domestic altruistic surrogacy community in the UK.Yet in particular, those women and men who are not celebrities and not members of the racially dominant groups or middle class face many challenges in family formation (Patton-Imani 2020).

LGBTQ people's ability to employ reproductive technologies and fertility services, including adoption, also continues to be severely curtailed in those regions of the world or religious contexts where these practices and treatments are still criminalized or not recognized as a legitimate pathway to parenthood. In Europe, in several countries, state-subsidized IVF is limited to married heterosexual couples; in most countries, it is not legal to carry out surrogacy (e.g., Courduriès 2018; Guerzoni 2020); and in most of Central and Eastern Europe, lesbian and gay people do not have any rights as families at all (Mizielińska and Stasińska 2019). In an ethnography of Italian gay parents, Corinna Guerzoni (2020) found that legal restrictions drove LGBTQ intended parents to travel to gain access to surrogacy arrangements. Genetic links between parents and the child are legally recognized in Italy, a nation that prohibits adoption by LGBTQ couples and single people. Intended parents who live in European jurisdictions such as Italy and possess the economic resources to travel began to enter surrogacy contracts in North America, primarily the United States, as well as other locations where transnational surrogacy is now banned such as India, Mexico, and Thailand (Twine 2015).

\section{First wave of ethnographic studies on gay and lesbian families}

In the late twentieth century, gays and lesbians in the US, UK, and elsewhere created their "chosen families" with friends who provided genetic material, co-parenting arrangements, and in some cases adoption. This was an era when IVF and surrogacy were not yet widely available to queer families (Weston 1991; Donovan et al. 2001). Kath Weston (1991) characterized this period as one of "exile from kinship" by gays and lesbians' families of origin.

In Kath Weston's Families We Choose (1991), lesbian and gay families in the US revealed "the potential of chosen kin to expand the notion of family well beyond couples and kids," as Weston remarked in the 1997 edition of her book. The book cover of this edition is powerful and reflects the emphasis on intimacy. Representing an era in which working-class Black, Puerto Rican, and Dominican men revolutionized both performance art and queer family formation, Weston chose a photograph of three young men from one of the voguing houses in New York who represent the familial bonds of chosen kinship (Weston 1997: xvii-xviii). This form of kin- 
ship, not linked by blood ties but by a form of commitment and love, has long been normative in Black and Latino queer communities (Weston 1991:36, 56).

Whites without a strong ethnic identification often described coming out as a transition from no community into community, whereas people of color were more likely to focus on conflicts between different identities instead of expressing a sense of relief and arrival.

(Weston 1991: 134)

Race and ethnicity were also mentioned by lesbian lovers who were planning to get pregnant and were searching for a sperm donor:

[My lover] said:"I really want an Hispanic to give me sperm, so that the baby looks like you" [...] Resemblance between parent and child might signify an intention toward creating ethnic or cultural continuity (popularly understood as passing along "traditions"), as well as the union of the child's parents.

(Weston 1991: 189)

Alongside the state as well as families and communities of origin, queer people also negotiated their family formation projects within the hierarchies of gender. Ellen Lewin (1993) showed that in becoming mothers, lesbian women in the US followed the culturally dominant narratives of gender:They emphasized their identities as women whilst downplaying their sexuality. Gendered narratives also shaped the family projects of gay men, as Lewin (2009) discussed in her ethnography of gay fatherhood in the US. The gay men whom Lewin interviewed longed for "normal" families with children, in a context where becoming children's primary caregivers was not so common for men. Likewise, Judith Stacey (2006) found that most of the US gay men she interviewed were "situational parents." Only very few of Stacey's interviewees considered themselves "predestined parents," and many of them became fathers only due to their partners' exceptional determination.

Although these early pioneering ethnographic studies did not explore race as a significant force that structured queer family formation, they laid the theoretical foundation for later research. The early ethnographies of lesbian and gay families belonged to a historical moment where it was much more common than today to experience exile from kinship due to one's sexuality. The contribution of those early studies was showing that non-heteronormative ways of forming families existed.

\section{Likeness and whiteness: Racial matching in multiethnic and monoethnic family formation}

In White Women, Race Matters: The Social Construction of Whiteness, Ruth Frankenberg (1993) generated a new set of concepts to think through racial consciousness. A white Jewish lesbian feminist and anti-racist, Frankenberg earned her undergraduate degree in anthropology at Cambridge (UK), followed by a Ph.D. from the University of California. Drawing upon interviews with White women in northern California, her positionality and commitment to anti-racism informed her research. Frankenberg's intervention was to flip the script and shift the focus to members of the racially dominant group. In mapping out her intellectual project, Frankenberg writes:

My argument in this book is that race shapes white women's lives. In the same way that both men's and women's lives are shaped by their gender, and that both heterosexual 
and lesbian women's experiences in the world are marked by their sexuality, white people and people of color live racially structured lives.

(Frankenberg 1993: 1)

But White people historically have been able to represent the norm that is racially unmarked. One privilege or marker of being White is not having to think about race. This changes when individuals form families either through adoption or IVF/surrogacy. Men and women are then confronted with the issue of difference as measured by race and class. Frankenberg defines whiteness as:

a set of linked dimensions. First, whiteness is a location of structural advantage, of race privilege. Second, it is a "standpoint," a place from which white people look at ourselves, at others, and at society. Third, "whiteness" refers to a set of cultural practices that are usually unmarked and unnamed.

(1993: 1).

Frankenberg's theoretical project was focused on the racial consciousness of White women in the United States during the late 1980s. However, we can apply her concepts to gay and lesbian parents, who are racialized. Her concept of race, color, and power-evasive discourses is useful when we consider how potential parents conceptualize or minimize the meaning of race as an axis of difference in their lives.

In a 2008 review of the field of whiteness studies, a field that is the daughter of Black studies, France Winddance Twine and Charles Gallagher (2008) examined emerging trends as the field moved from its US origins and became more international. In the 1990s, an interdisciplinary body of literature detailed how "whiteness" as a collective identity was an achievement (Brodkin 1998; Jacobson 1998; Smedley 1993). Anthropologists and historians have detailed the instability of race as an idea and a material formation. It has to be enforced by the state. Family formation has long been a struggle, in which interracial and same-sex families have been criminalized and perceived as disruptive, dangerous, and transgressive compared to the idealized middle-class, monoracial heterosexual family form. The modern idea of race as a "fact" and a shared identity is a product of European colonialism that ranked people and attributed intellectual and moral capabilities to physical traits (Smedley 1993). The former British colonies share this idea, even if within them the boundaries of who was eligible for whiteness shifted and varied over time and space. In the case of India, this was added to a much older and more complex caste system (called varna by the Hindus).

There are clear parallels between the forms of discipline that transgressive couples endured, which positioned interracial relationships and same-sex families as legally and culturally "queer." This way, due to the prohibition of interracial and same-sex kinships and property transfer, they could not produce economic support for their kinships either (cf. Russell 2018). Queer families, like their transnational and interracial contemporaries, continue to occupy a vulnerable status in most states. Even if tolerated to a varying extent depending on the place, queer families in the global context still do not enjoy the same civil rights or benefits of recognition of heterosexual couples (see Mizielińska and Stasińska 2019 on Poland; Gradskova et al. 2020 on Russia; Guerzoni 2020 on Italy). One consequence is that the global market in reproductive technologies is shaped, in part, because of the denial of the right to form a family for queer couples and individuals in some regions of the world. What is more, some technologies such as surrogacy are not a legally recognized pathway to parenthood not even for many heterosexual couples in some regions of the world such as most of Europe. This is another layer in the multiple barriers that queer people face. 


\section{New directions: Choreography of race in queer kinship}

Inspired by Charis Thompson's (2005) “ontological choreography," we propose the term choreography of queer kinship. In Thompson's ethnography of fertility clinics in the US, patients emphasized or de-emphasized various kinds of biological connections they had to their children, in order to disambiguate their kinship ties. It was choreographed within a broader ontological choreography: "the dynamic coordination of the technical, scientific, kinship, gender, emotional, legal, political, and financial aspects of ART clinics” (Thompson 2005: 8).

Thompson included logic of this kind within the mechanisms of "strategic naturalization," whereby biology may be infused with social meanings, and it may be mobilized in different ways in order to disambiguate kinship (2005: 155-158). Feminist scholars such as Thompson, Sarah Franklin (2013), and Marilyn Strathern (1992) have shown that while there are no "natural grounds" or "pure biology" to form a basis for designating kinship, nevertheless meanings of biology and nature are used and mobilized in diverse ways in order to designate kinship. For example, the female IVF patients studied by Thompson chose egg donors with whom they thought they shared some ethno-racial heritage, even if the donors would not be regarded as mothers: "Eliding ethnonational and race- and class-based categories with natural grounds for designating kinship is a strategy fundamental to bilateral, blood-based kinship systems" (Thompson 2005: 172).

Scholars have found that in India and Israel, the choreography of matching is central to donors and gestational surrogates. In Israel, Elly Teman (2010) details how halakhah (Jewish religious law) requires Jews from different regional and racialized backgrounds to be matched. In India, surrogates must adhere to particular forms of domesticity which are also modeled on caste and religious lines, exemplified by the figure of the domestic worker (Majumdar 2018). As Anindita Majumdar (2018) showed in her ethnographic research on surrogacy in India, intended parents often perceive women belonging to different caste and religious groups with mistrust, which was found to happen particularly often in the case of Hindu intended parents hiring Muslim surrogates, and middle-class parents hiring surrogates that share the position of paid domestic servants. In this kind of choreography, queer kinship often reproduces caste and class inequalities within and across religious communities.

\section{The unsteady marriage of queer studies and critical race studies}

Scholars studying lesbian and gay family formation have found a complicated choreography of sexuality, race, and class in the US, the UK, Australia, and Western Europe (Mamo 2007; Murphy 2015; Stacey 2006; Taylor 2009; for a detailed review please see Smietana, Thompson, and Twine 2018). In the United States, heteronormativity, racial exclusivity, and class privilege structured access to assisted reproductive technologies. When lesbian and gay couples employ ART (such as IVF and surrogacy), their class status and racial identities continue to play a key role in the reproduction of structural inequalities. Predominantly White and middle-class gays and lesbians were the first and also the majority of LGBTQ people who got access to ART.

In a qualitative study of lesbian mothers in the US, Laura Mamo (2007) found that "sperm banks highlight cultural beliefs about sperm, race, heredity, social desirability, and power, beliefs that women draw on when making their selection choices" (203). The lesbians who participated in Mamo's study gave careful consideration to the sperm donor's "racial and ethnic background or religious ancestry" (205). In fact, they were key factors in their selection criteria. Mamo found that donor selection served as a "kinship device, it was driven by their perception that cultural matching was materialized in physical likeness": 
[A] kinship device ... enables the recipients to envision their own social connections to the imagined children. Kinship becomes relational: potential mothers select donor characteristics they might share with — that is, have in common with-potential offspring. These attributes are not only physical but also social and cultural. [...] Affinity ties are also central to imagining future relationships outside the family as providing potential social legitimacy. This was most clear in racial-ethnic decisions to select a donor who "matched" both mothers when they were of the same ethnicity or to select based on the ethnicity of the "nonbiological" mother-to-be.

(2007: 206)

Mamo was not the only one to identify racial identity and perceptions of whiteness $-\mathrm{a}$ form of social privilege in the United States-as key components in donor selection (see Thompson 2009). The practice of racial matching of gamete sperm donors has also been found in recent research on families formed by lesbian couples in other English-speaking countries such as the UK and Australia, where whiteness is a form of cultural, social, and symbolic capital that provides many life-long advantages (Nordqvist 2012; Andreassen 2017; Davda 2018). Promoting whiteness as an ideal in gamete donation within state-controlled fertility clinics, and discouraging interracial gamete donation was also identified in Northern Europe. As Ulrika Dahl (2018) concluded from her ethnographic research with LGBTQ parents who sought treatment at fertility clinics in Sweden, "queer kinship, despite all its utopian fantasies can work as a reproductive technology for whiteness" (205). Racial matching can, however, be used in a different way by interracial couples. The interracial lesbian couples interviewed by Alyssa M. Newman (2019) in the US faced a "bio-matching tradeoff": they prioritized racial similarity either between a child and their siblings or between a child and a mother.

In a cross-national comparative study, Dean Murphy (2015) analyzed the use of IVF surrogacy among Australian and American gay father families. Their use of biogenetic understandings of kinship presented challenges for gay male couples, who employed creative strategies to enhance or obscure biogenetic links. Like lesbian couples in other studies, they selected reproductive material with the intention of creating families that shared phenotypic characteristics, between both male parents and the children, as well as, in some cases, between the children and the broader society (Murphy 2015: 152). What is more striking is that the men in this study matched the ethnic background of the egg donor to the non-biogenetic father. For all the interviewees, "likeness was important in conveying the message of a coherent family unit and in enacting kinship" (Murphy 2015: 156-157). "Kinship is also enacted through [...] the attribution of physical and other resemblances that can stand in for biogenetic links or, more interestingly, sometimes supplant them" (Murphy 2015: 160).

In striking contrast to Mamo and Murphy, Jaya Keaney (2019), in her study of Australian queer families created by assisted reproductive technologies, found quite the opposite, as we discuss in the section below. Keaney's research represents the frontier of an emerging body of empirical literature that contributes significant and original theoretical insights. In fact, she conceptualizes the queer multiracial family in her study as "an emergent kinship form" (80). She argues:

Where past Anglophone literature, public culture, and clinical practice around assisted reproduction have centered on the white, heterosexual, middle-class infertile couple, the queer multiracial family is emerging as a powerful emblem of the drastic changes in the landscape of contemporary kinship. This demands our scholarly attention.

(Keaney 2019: 80) 
Following Sarah Franklin (2013, 2019), we situate Keaney's work in this neo-colonial moment, in which in former British colonies and the larger Anglophone world, whiteness continues to be a valuable form of property (Harris 1993). However, the changing cultural climate in which many countries have recently removed state barriers to same-sex marriage, a cultural space exists for queer multiracial families to counter the dominant representations of the idealized family as White, monoracial, and heterosexual.

\section{Toward racial literacy}

Racial literacy is a set of practices that France Winddance Twine (2010) identified in interracial families of White British mothers who had Black male partners and who had learned to counter racism and the "queerness" of their interracial relationships and mixed-race children:

the concept of racial literacy, an analytical orientation and a set of practices that reflect shifts in perceptions of race, racism and whiteness. It is a way of perceiving and responding to racism that generates a repertoire of discursive and material practices. The components of racial literacy include the following: (1) the definition of racism as a contemporary problem rather than a historical legacy; (2) an understanding of the ways that experiences of racism and racialization are mediated by class, gender inequality, and heterosexuality; (3) a recognition of the cultural and symbolic value of whiteness; (4) an understanding that racial identities are learned and an outcome of social practices; (5) the possession of a racial grammar and vocabulary to discuss race, racism, and antiracism; and (6) the ability to interpret racial codes and racialized practices.

(Twine 2010: 92)

The concept of racial literacy enables us to better understand the complex emotional and cultural negotiations that LGBTQ people make as they negotiate stigma and structural racism, as they consider "who" they will reproduce in socio-racial terms. In other words, as Twine (2010) has argued, our racialized bodies are social products - that is, they are "read." These readings shape how one is treated as a racialized actor outside of the family. Following Erving Goffman (1963), we remind the reader that race can be thought of as a performance. Although Goffman's work preceded critical race studies and was not attentive to gender expression as we understand it today, nevertheless, he provided a theory that helps us understand "impression management." In his analysis of the management of stigma, Goffman argues that individuals will try to conceal and "pass" as normal. To some extent we see the same process operates among people who experience social or class mobility (middle- and upper-middle-class LGBTQ) and who consider how racialized bodies have to be managed.

Camisha Russell (2018) provides a perspective that has been largely missing in the debate, both as a philosopher, a Black lesbian mother, and a participant in the ART industry. In her analysis, Russell employs and builds upon arguments made by historians, anthropologists, and sociologists. She demonstrates how race is an "ideal" that is given materiality through everyday practices. One example is her discussion of scroll-down menus at in/fertility clinics:

The existence of drop-down menus for race and ethnicity on sperm bank web pages are, on the one hand, a stark reminder of the deep social practices that have divided and continue to organize people in terms of race. The fact that the existence of such drop-down menus is not seen as strange or regressive, on the other hand, reveals how race is still fundamentally viewed as the natural outcome of reproduction.

(Russell 2018: 160) 
Russell argues it would not be wise to impose any definite answers at the individual or policy level as to how one should approach a scroll-down menu in a fertility clinic. What is more, she argues that "racial selection is always taking place in ARTs" (Russell 2018: 160), and that "enforcing a sort of race 'blindness' in ART would be troublesome" (161) for a series of reasons, including "a lack of respect for the fact that, no matter what their history, the categories of race and ethnicity can have rich cultural meanings" (161). She reminds that

the role of race in assisted reproduction does not stand apart from its role in nonassisted reproduction. As long as race, racism, and racial privilege continue to operate in the larger contexts of sex, marriage, reproduction, and kinship, it will do little good to regulate the reproductive behavior of that portion of the population who must seek assistance in having children.

(Russell 2018: 161)

She notes, however, that reproduction, and in particular, assisted reproduction, is an interesting site for the critical study of race. She recommends "the ongoing practice of social- and self-critique among those who use, administer, legislate and think about ARTs" (Russell 2018: 164). Given the need for such a critique, a number of scholars have argued that we need racial literacy - that is, a critical vocabulary to address structural racism (Eng 2010; Twine 2010).

Racial literacy as a component of making kinship may be a remedy to "colorblindness." This has also been suggested by Sandra Patton-Imani (2020) in her study of lesbian mothers of different racial-ethnic identifications and socioeconomic statutes in the US:

In both social interactions and legal regulations, enactments of "colorblindness" depend upon the denial and erasure of any reference to race, foreclosing social recognition of racial "difference" (from whiteness, the unmarked norm). Within this system of racial meaning, noticing race is equated with racism, and this unfortunately translates too often to both the denial of racism as a structural issue, and the erasure of the ways that race informs people's senses of self, others, and society. [...] Colorblindness, grounded in erasure and evasion, intersects with patriarchy, heteronormativity, and capitalism to naturalize and normalize the family forms that support contemporary boundaries of legitimacy and citizenship.

$(16-17)$

\section{Racial logics and racial threats}

In the research on queer families that we have reviewed, a recurring theme is the threat that recognizing race and racism can pose to intended parents who self-identify as White (and belong to the racially dominant group) as well as parents who are marked as ethnic. In his research on gay male couples forming families in Spain, Marcin Smietana (2016) found this same discursive strategy to manage “difference." As one of Smietana's interviewees said:

We didn't want to add extra difficulties for our son, like being very blond in a country where people are not so blond, or being Black when there are so few Black people in this country. I think by the fact of having two fathers and the fact of having been born through surrogacy, he is already different enough from his peers.

(Smietana 2016: 55) 
In her analysis, Jaya Keaney (2019) argues that donor catalogues reproduce and sustain nineteenthcentury racial logics and classification schemes (cf. Russell 2018). Assisted reproductive technologies, like all technologies, can be deployed to both challenge and reproduce structural racism.

Cataloging gamete providers by race reinforces the pervasive idea that race is inheritable, reified in genetics and biologically transmissible. Despite decades of antiracist work disproving the genetic basis of race, this popular conception has only gained traction in our current "post-genomic age," where the gene is increasingly the locus of cultural identity and life itself. Ordering providers of gametes as cataloged options also creates a sense of equivalence, flattening race as one characteristic among many.

(Keaney 2019: 87)

Keaney's primary finding was that intended parents treat race as invisible. Returning to Frankenberg (1993), we see that Keaney's interviewees in Australia employed race and colorevasive discourse. The gay parents in Keaney's study deemed their children's darker skin color as irrelevant, which she interpreted as a reflection of their beliefs about a "post-racial" multicultural Australian society.

This detachment is particularly evident in the way a child's racialized body and cultural identity were separated in my interviews. When I asked Stuart whether he would foster connections to Thai or Indian culture in his daughters, he said it was not a priority, because they are "Australian children ... they're part of our family."

(Keaney 2019: 88-89)

The participants in Keaney's study are not unique in their efforts to deflect away from the realities of racism and racial hierarchies. This has been found in other studies of families (Twine 2010; San Román 2013). In Spain, Beatriz San Román (2013) found this same discursive move in interracial families formed by international adoption.

Unlike children who arrive in Spain with their migrant families, transracial adoptees usually have had very limited access to other identity discourses than those of the hegemonic social groups. Most of those families adopting transnationally belong to the upper middle or upper class. Their children are raised and socialised in and by the dominant 'white' culture and have little opportunities to engage into horizontal relationships with non-white people ... In Spain, ..., transracial adoptees have often been the only non-whites in their environment, with no class or work mates nor friends or inlaws who were not white.

(San Román 2013: 231)

Research on queer multiracial families is moving queer studies into new directions. Sandra Patton-Imani's (2020) research is an exemplary model of a queer study that is engaged with critical race studies. In Queering Family Trees: Race, Reproductive Justice and Lesbian Mothers, PattonImani offers a critique of the normative family genealogies and calls for queering them: Giving legitimacy, both social and legal, to those kin, past and contemporary, who are unrecognized and invisible. This may refer, as she says, to restoring to the family trees "illegitimate" Black grandmothers who were raped by one's "legitimate" White grandfathers and erased from respectable family trees. Between 2004 and 2010, Patton-Imani (the author) and her partner Melanie-an interracial lesbian couple - conducted interviews with more than 100 lesbian and queer mothers of diverse racial and class backgrounds across the US. Patton-Imani's goal was to examine 
the ways lesbian mothers navigate family-making in social and legal contexts that define queer families as illegitimate.

Prior to 2015, before the Supreme Court recognized same-sex marriage as a legal right, each state had its own laws regulating marriage and adoption. Before federal recognition of same-sex marriage, "parents had to purchase legal protection" (Patton-Imani 2020: 7). Marriage was a vehicle that provided access to many family-related rights and privileges of citizenship. Race and class structure the possibilities of queer kinship both in those states that respected gay marriage and, even more, in those that did not. "Basic protections that heterosexually married couples take for granted became high-cost consumer goods that were out of reach for many of the families we talked with" (Patton-Imani 2020: 7).

Natali Valdez and Daisy Deomampo have argued that "contemporary research on reproduction requires increased attention to the nuanced workings of race, racism and racialization" (2019: 555). Khiara Bridges observed,

while surrogacy arrangements are beneficial because they enable persons who are unprivileged by virtue of sexual orientation to have children, they may reaffirm extant racial hierarchies and exacerbate the marginalization of persons and families that are already unprivileged by virtue of race and class.

(2014: 1125)

Thus, alongside understanding the narratives of the people who take part in our research, we need to understand how their choices are linked to broader social structures and their histories (see also Lopez in this volume).

\section{Conclusion}

A careful and critical analysis of how, by whom, and for what purposes race is mobilized in reproduction is a crucial task for anthropological studies of reproduction. Sara Ahmed has called for a "politics of disorientation" as a queer political project (2006: 142). This is a type of racial literacy project that demands a new set of studies of queer families that place race and class inequality at the center of queer family formation. The failure to problematize race in earlier anthropological studies has unwittingly reinforced an idealized model of the family as monoracial - one in which difference is perceived as a problem - a stigma to be resolved. The costs of presuming that racism is secondary — as Jasbir Puar (2007) and David Eng (2010) have warnedare what motivates us to echo Ahmed's queer political project designed to trouble the privileging of whiteness and heterosexuality.

\section{Acknowledgments}

We would like to thank Professors Sarah Franklin, Marcia Inhorn, Charis Thompson, and Anindita Majumdar and Dr. Doris Leibetseder for their intellectual guidance, funding, and collaborative work as co-conspirators. The paper was written with support from the Wellcome Trust (Grant no. 209829/Z/17/Z). Both authors have contributed equally to writing this chapter.

\section{References}

Ahmed, Sara. 2006. Queer Phenomenology. Duke University Press, Durham, NC.

Ahmed, Sara. 2011. Problematic proximities: Or why critiques of gay imperialism matter. Feminist Legal Studies 19 (August): 119. 
Andreassen, Rikke. 2017. Social imaginaries, sperm and whiteness: Race and reproduction in British media. Journal of Intercultural Studies 38 (2): 123-138.

Anzaldúa, Gloria. 1981[2009]. La Prieta. In: Keating, AnaLouise (Ed.), The Gloria Anzaldúa Reader. Duke University Press, pp. 38-50. https://doi-org.ezp.lib.cam.ac.uk/10.1215/9780822391272

Bacchetta, Paola, and Haritaworn, Jin. 2011. There are many transatlantics: Homonationalism, homotransnationalism and feministqueer-trans of colour theories and practices. In: Davis, Kathy and Evans, Mary (Eds.), Transatlantic Conversations: Feminism as Travelling Theory. Routledge, London and New York, pp. 127-144.

Bridges, Khiara. 2014. Windsor, surrogacy, and race. Washington Law Review 89(4): 1125-1153.

Briggs, Laura. 2017. How All Politics Became Reproductive Politics. University of California Press, Oakland.

Brodkin, Karen. 1998. How Jews Became White Folks and What That Says about Race in America. Rutgers University Press, New Brunswick, NJ.

Courduriès, Jérôme. 2018. At the nation's doorstep: The fate of children in France born via surrogacy. Reproductive Biomedicine and Society Online 7. DOI: 10.1016/j.rbms.2018.11.003.

Dahl, Ulrika. 2018. (The promise of) monstrous kinship? Queer reproduction and the somatechnics of sexual and racial difference. Somatechnics 8 (2): 195-211. DOI: 10.3366/soma.2018.0250

Davda, Priya. 2018. The (Bio)Medicalisation, Stratification and Racialisation of Reproduction through Matching in UK Egg Donation. Doctoral dissertation, Royal Halloway and Bedford New College University of London.

De Lauretis, Teresa. 1991. Queer theory: Lesbian and gay sexualities. An introduction. Differences: A Journal of Feminist Cultural Studies 3 (2): III-XVIII.

Donovan, Catherine, Heaphy, Brian, and Weeks, Jeffrey. 2001. Same Sex Intimacies: Families of Choice and Other Life Experiments. Routledge, London and New York.

Duggan, Lisa. 2002. The new homonormativity: The sexual politics of neoliberalism. In: Castronovo, Russ and Nelson, Dana D. (Eds.), Materializing Democracy: Toward a Revitalized Cultural Politics. Duke University Press, Durham, NC, pp. 175-194.

Eng, David. 2010. The Feeling of Kinship: Queer Liberalism and the Racialization of Intimacy. Duke University Press, Durham.

Frankenberg, Ruth. 1993. White Women, Race Matters: The Social Construction of Whiteness. University of Minnesota Press, Minneapolis, MN.

Franklin, Sarah. 2013. Biological Relatives: IVF, Stem Cells and the Future of Kinship. Duke University Press, Durham and London.

Franklin, Sarah. 2019. A tale of two halves?: IVF in the UK in the 1970s and 1980s. In: Mackie, Vera, Marks, Nicola J., and Ferber, Sarah (Eds.), The Reproductive Industry: Intimate Experiences and Global Processes. Lexington Books. Lanham, Boulder, New York, London, pp. 15-30.

Goffman, Erving. 1963. Stigma: Notes on the Management of Spoiled Identity. Simon \& Schuster, New York.

Goodfellow, Aaron. 2015. Gay Fathers, Their Children, and the Making of Kinship. Fordham University Press, New York.

Gradskova, Yulia, Kondakov, Alexander, and Shevtsova, Maryna. 2020. Postsocialist revolutions of intimacy: An introduction. Sexuality \& Culture 24: 359-370. DOI: 10.1007/s12119-020-09706-8.

Guerzoni, Corinna Sabrina. 2020. Sistemi Procreativi: Etnografia dell'omogenitorialità in Italia. FrancoAngeli, Milano.

Harris, Cheryl. 1993. Whiteness as property. Harvard Law Review 106 (8, June): 1707-1791.

Hunter, Margaret. 2002. "If you're light, you're alright": light skin color as social capital for women of color. Gender \& Society 16(2): 175-193.

Hunter, Margaret. 2007. The persistent problem of colorism: Skin tone, status, and inequality. Sociology Compass 1(1): 237-254.

Jacobson, Matthew Frye. 1998. Whiteness of a Different Color: European Immigrants and the Alchemy of Race. Harvard University Press, Cambridge, MA.

John, Elton. 2019. Me: Elton John Official Autobiography. Henry Holt, New York.

Keaney, Jaya. 2019, Queer multiracial family: Figuring race in donor-assisted conception. In: Mackie, Vera , Marks, Nicola J., and Ferber, Sarah (Eds.), The Reproductive Industry: Intimate Experiences and Global Processes. Lexington Books, Lanham, Boulder, New York, London, pp. 79-95.

Lewin, Ellen. 1993. Lesbian Mothers: Accounts of Gender in American Culture. Cornell University Press, Ithaca and London.

Lewin, Ellen. 2009. Gay Fatherhood: Narratives of Family and Citizenship in America. The University of Chicago Press, Chicago and London. DOI: 10.1016/j.rbmo.2011.09.016. 
Majumdar, Anindita. 2018. Conceptualizing surrogacy as work-labour: Domestic labour in commercial gestational surrogacy in India. Journal of South Asian Development 13(2) 1-18. DOI: 10.1177/0973174118778481.

Mamo, Laura. 2007. Queering Reproduction: Achieving Pregnancy in the Age of Technoscience. Duke University Press, Durham.

Mizielińska, Joanna, and Stasińska, Agata. 2019. Negotiations between possibilities and reality: Reproductive choices of families of choice in Poland. European Journal of Women's Studies: 1-16. DOI: 10.1177/1350506819887765.

Murphy, Dean A. 2015. Gay Men Pursuing Parenthood through Surrogacy: Reconfiguring Kinship. University of New South Wales Press, Sydney.

Newman, Alyssa M. 2019. Mixing and matching: Sperm donor selection for interracial lesbian couples. Medical Anthropology 38 (8): 710-724, DOI: 10.1080/01459740.2019.1655737.

Nordqvist,Petra.2012.I don't want us to stand out more than we already do':Lesbian couples negotiating family connections in donor conception. Sexualities 15 (5-6):644-661. DOI: 10.1177/1363460712446271.

Patton-Imani, Sandra. 2020. Queering Family Trees; Race, Reproductive Justice, and Lesbian Motherhood. New York University Press, New York.

Puar, Jasbir. 2007. Terrorist Assemblages: Homonationalism in Queer Times. Duke University Press, Durham and London.

Russell, Camisha. 2018. The Assisted Reproduction of Race. Indiana University Press, Bloomington.

San Román, Beatriz. 2013. "I am white... even if I am racially black"; "I am Afro-Spanish”: Confronting belonging paradoxes in transracial adoptions. Journal of Intercultural Studies 34 (3): 229-245.

Smedley, Audrey. 1993. Race in North America: Origin and Evolution of a Worldview. Boulder, CO: Westview Press.

Smietana, Marcin. 2016. 'Families like we'd always known'? Spanish gay fathers' normalization narratives in transnational surrogacy. In: Lie, Merete and Lykke, Nina (Eds.), Assisted Reproduction across Borders: Feminist Perspectives on Normalizations, Disruptions and Transmissions, pp. 49-60. Routledge, London and New York.

Smietana, Marcin. 2017. Affective de-commodifying, economic de-kinning: Surrogates' and gay fathers' narratives in U.S. surrogacy. Sociological Research Online 22(2): 163-175. https://doi.org/10.5153/sro .4312 .

Smietana, Marcin, Thompson, Charis, and Twine, France Winddance. 2018. Making and Breaking Families: Reading Queer Reproductions, Stratified Reproduction and Reproductive Justice Together. Reproductive Biomedicine and Society Online, Vol. 7, November. DOI: 10.1016/j. rbms.2018.11.001

Smietana, Marcin and France Windddance Twine. n.d."Queer decisions: Racial matching and stigma management among gay male intended parents."

Stacey, Judith. 2006. Gay parenthood and the decline of paternity as we knew it. Sexualities 9 (1): 27-55. DOI: $10.1177 / 1363460706060687$.

Strathern, Marilyn. 1992. Reproducing the Future: Anthropology, Kinship and the New Reproductive Technologies. Routledge, New York.

TallBear, Kim. 2018. Making love and relations beyond settler sex and family. In: Clarke, Adele, and Haraway, Donna (Eds.), Making Kin Not Population. Prickly Paradigm Press, Chicago, pp. 145-164.

Taylor,Yvette. 2009. Lesbian and Gay Parenting: Securing Social and Educational Capital. Palgrave Macmillan, Basingstoke and New York.

Teman, Elly. 2010. Birthing a Mother: The Surrogate Body and the Pregnant Self. California University Press, Berkeley.

Thompson, Charis. 2005. Making Parents: Reproductive Technologies and Their Ontological Choreography. MIT Press, Cambridge MA.

Thompson, Charis. 2009. Skin tone and the persistence of biological race in egg donation for assisted reproduction. In: Glenn, Evelyn Nakano (Ed.), Shades of Difference: Why Skin Color Matters. Stanford University Press, Stanford, CA, pp. 131-147.

Twine, France Winddance. 2010. A White Side of Black Britain: Interracial Intimacy and Racial Literacy. Duke University Press, Durham and London.

Twine, France Winddance. 2015. Outsourcing the Womb: Race, Class, and Gestational Surrogacy in a Global Market. 2nd edition. Routledge, New York.

Twine, France Winddance, and Gallagher, Charles. 2008. The future of whiteness: A map of the 'third wave'. Ethnic and Racial Studies 31 (1): 4-24. DOI: 10.1080/01419870701538836 
Valdez, Natali, and Deomampo, Daisy. 2019. Centering race and racism in reproduction. Medical Anthropology 38 (7): 551-559. DOI: 10.1080/01459740.2019.1643855

Weston, Kath. 1991. Families We Choose: Lesbians, Gays, Kinship. Columbia University Press, New York.

Weston, Kath. 1997. Families We Choose: Lesbians, Gays, Kinship. $2^{\text {nd }}$ ed. New York: Columbia University Press. 